\title{
Range Extension for Pygmy Whitefish (Prosopium coulterii) in the Northwest Territories, Canada
}

\author{
Paul Vecsei ${ }^{1}$ and Damian Panayi \\ Golder Associates Ltd., 9-4905 48th Street, Yellowknife, Northwest Territories X1A 3S3 Canada \\ ${ }^{1}$ Corresponding author: pvecsei@golder.com
}

Vecsei, Paul, and Damian Panayi. 2015. Range extension for Pygmy Whitefish (Prosopium coulterii) in the Northwest Territories, Canada. Canadian Field-Naturalist 129(1): 70-75.

We document the first occurrence of Pygmy Whitefish (Prosopium coulterii) in the Northwest Territories outside of Great Bear Lake. Six specimens were captured in Bluefish Lake in September 2012. Bluefish Lake is on the Yellowknife River, approximately $25 \mathrm{~km}$ upstream from Great Slave Lake.

Key Words: Range extension; Pygmy Whitefish; Prosopium coulterii; Northwest Territories; Coregoninae; distribution; Bluefish Lake; Yellowknife Lake; Great Slave Lake

\section{Introduction}

The Pygmy Whitefish (Prosopium coulterii) is the smallest member of the subfamily Coregoninae. It has large scales, large eyes, a blunt snout with a subterminal mouth, and a cylindrical body. Its gill rakers are short and number between 13 and 20. Scales along the lateral line range between 54 and 70 (Eschmeyer and Bailey 1955). The Pygmy Whitefish is typical of fishes in the genus Prosopium in having a single internarial flap (McPhail and Lindsey 1970). Colouration is typically brownish along the dorsum with dark parr marks even in adults (Scott and Crossman 1973; Nelson and Paetz 1992; Mecklenburg et al. 2002). Ventral fins of both sexes become dark yellow or orange during spawning (Heard and Hartman 1965). Fecundity is lower than other coregonids, with egg production ranging from 97 to approximately 1000 (Weisel et al. 1973). Mean egg size in Alaska was $2.4 \mathrm{~mm}$ (Heard and Hartman 1965). Although the largest recorded egg size is $262 \mathrm{~mm}$ (McCart 1963), the maximum size rarely exceeds $140 \mathrm{~mm}$ (Eschmeyer and Bailey 1955; Mackay 2000*).

The Pygmy Whitefish has a wide discontinuous distribution in North America (Scott and Crossman 1973; Hallock and Mongillo 1998*; McPhail 2007* Sullivan 2011*) that includes Lake Superior (Ontario, Michigan, and Wisconsin); Yukon River drainage (northern British Columbia, Yukon, and Alaska); southwestern Alaska (Chignik, Naknek, and Wood River drainages); and the Columbia River drainage (western Montana, Washington, and British Columbia).

The Pygmy Whitefish has also been reported from Great Bear Lake, Northwest Territories, and Lake Athabaska, Saskatchewan (Nelson and Paetz 1992; Dr. Michael Sullivan, Provincial Fisheries Science Specialist, Sustainable Resource Development, Fish and Wildlife Division, Government of Alberta, personal communication, 2013) and from the Chukotski Peninsula in Russia (Chereshnev and Skopets 1992). The Pygmy Whitefish likely had a more continuous distribution during the late Pleistocene, but was isolated dur- ing the retreat of the Wisconsin glaciation (Eschmeyer and Bailey 1955).

In lakes, the Pygmy Whitefish ranges from shoreline habitat to waters as deep as $168 \mathrm{~m}$ (Heard and Hartman 1965; Lindsey and Franzin 1972). At northern latitudes, the species is most common in shallow water. Although the Pygmy Whitefish is typically lake dwelling, it also occurs in fast-moving montane rivers and streams that are clear or silted (McPhail and Lindsey 1970; Mayhood 1992*).

Spawning typically occurs in the late fall from November to December (Schultz 1941*; Weisel and Dillon 1954; Eschmeyer and Bailey 1955; McCart 1963; Heard and Hartman 1965; Hallock and Mongillo 1998*). Males mature at age 1 year and females at about 2 years (Wiesel et al. 1973). Maximum reported ages are typically 5-7 years (Eschmeyer and Bailey 1955).

\section{Methods}

We conducted a fish survey in Bluefish Lake from September 26 to October 1, 2012. Bluefish Lake is a natural widening of the Yellowknife River upstream from Prosperous Lake (Figure 1), and approximately $25 \mathrm{~km}$ upstream from Yellowknife Bay in Great Slave Lake.

Fish were collected using bottom-set, graded-mesh gillnets. Nets were $75 \mathrm{~m}$ long by $1.8 \mathrm{~m}$ high and composed of five, 15-m panels of 21.5-, 45.8-, 70.1-, 97.5-, and 120.4-mm stretched mesh. Nets were deployed overnight for more than $12 \mathrm{~h}$ at a depth of 25-33 m.

The entire catch was sorted and coregonids were processed as soon as possible after capture. A digital image of the left side of each individual was made using a Nikon D700 camera (Nikon Canada, Mississauga, Ontario, Canada). Fish were displayed on a flat pale pink surface with their fins pinned in the open position and a ruler added for scale (Figure 2). Dorsal views were also taken to illustrate spotting along the dorsal surface and flank. Each fish was individually bagged, labeled, and transferred to a freezer before processing in the laboratory. 


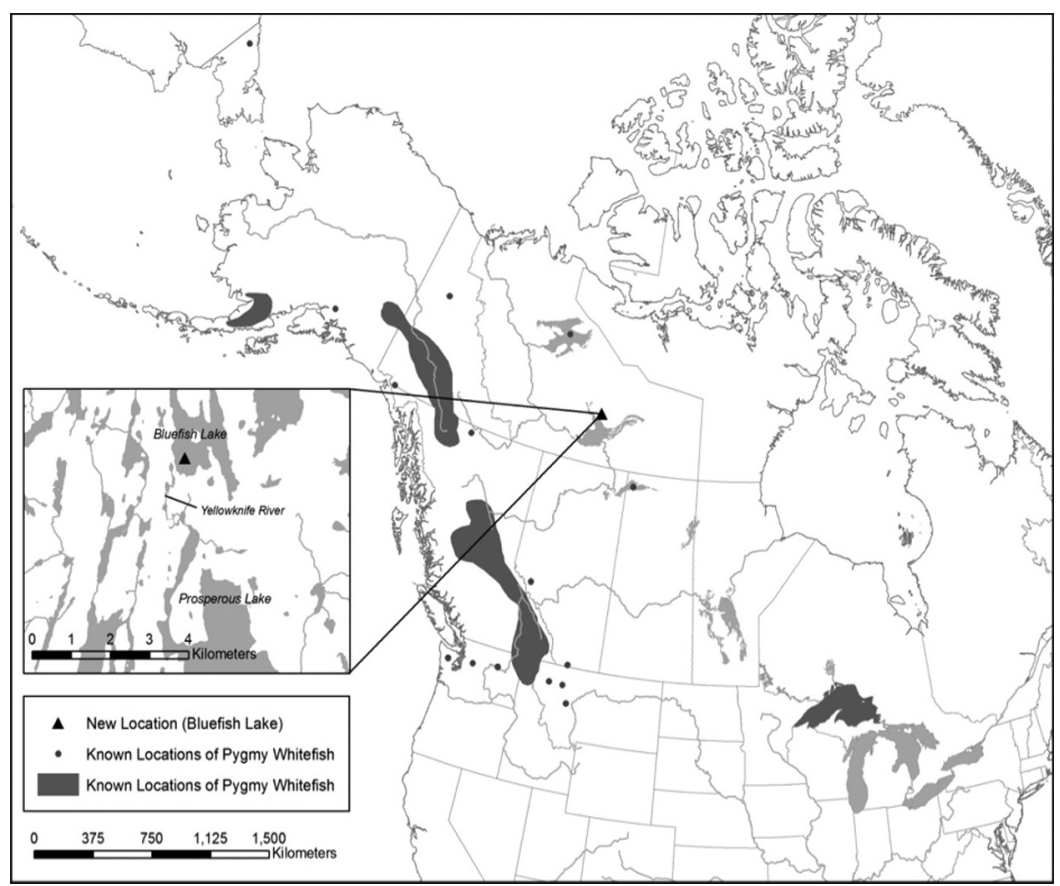

FIgURE 1. Distribution of the Pygmy Whitefish (Prosopium coulterii). Shaded areas and circles indicate known locations; the triangle shows the new location at Bluefish Lake, Northwest Territories.

Twenty-three linear morphometric and seven meristic characteristics were quantified following Vuorinen et al. (1993). All linear measurements were made pointto-point on the left side of the fish using digital calipers $( \pm 0.01 \mathrm{~mm})$. After measurements were made, the first left gill arch was extracted. Gill raker enumeration was done under a Leica ES2 dissection scope (Leica Microsystems Inc., Concord, Ontario, Canada) with reflect- ed light at a magnification between $10 \times$ and $30 \times$. All rakers were counted, including rudimentary rakers at the base of the arch. Scales in the lateral line were enumerated to the end of the hypural complex; where scales were missing because of damage during handling, scale pockets were counted. For fin ray enumeration, the anterior rays were excluded unless they were at least two-thirds the length of the longest ray. When

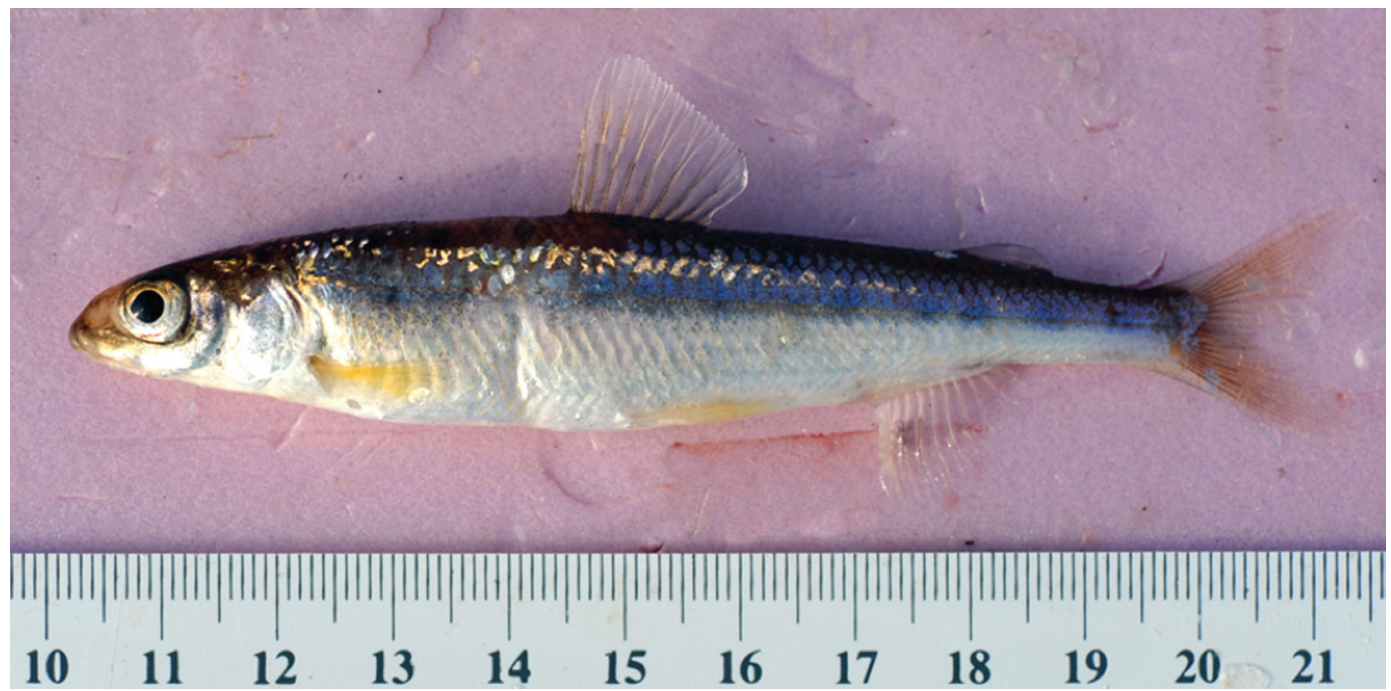

Figure 2. Pygmy Whitefish (Prosopium coulterii) captured in Bluefish Lake, Northwest Territories, 2012. 
the shortest ray was split at the base, it was counted as a single ray.

After morphometric and meristic measurements were completed, specimens were cut ventrally, and the body cavity was examined for sex determination. When ovaries were found intact, they were removed. Fecundity was determined by counting eggs under a Leica ES2 dissection scope. Six eggs from each of three females were measured. All fish were subsequently re-frozen and archived.

We compared our morphological and biological characteristics to Coregonidae descriptions (McPhail and Lindsey 1970; Scott and Crossman 1973; McPhail $2007 *$ ), paying closest attention to features unique to Pygmy Whitefish and to Prosopium species. The Pygmy Whitefish is often confused with juvenile Mountain Whitefish (Prosopium williamsoni) or Round Whitefish (Prosopium cylindraceum).

Water temperature $\left({ }^{\circ} \mathrm{C}\right)$, dissolved oxygen $(\mathrm{mg} / \mathrm{L})$, conductivity $(\mu \mathrm{S} / \mathrm{cm})$ and $\mathrm{pH}$ were recorded at the location and depth of the gillnet. An Ekman model E411196B12 bottom substrate retriever (Wildco, Yulee, Florida) was used to obtain bottom sediment at the sampling location. The bottom sediment sample was obtained from a single grab, described, and archived.

\section{Results}

Six individual Pygmy Whitefish, five females and one of unknown gender, with distinct stages of maturity were captured and examined. For general overall appearance, see Figure 2.

\section{Description}

Body small, fusiform, and streamlined; to $118 \mathrm{~mm}$ FL. Lumbar region moderate (15-19.5\% of standard total length (STL). Caudal peduncle elongate (15.2$18.2 \%$ of STL) and narrow (6.3-7.1\% of STL), body shallow, but variable (18.5-22.9\% of STL). Dorsal aspect of head moderately to highly convex in profile (i.e., straight line from the premaxilla to the occipital bone). Head depth shallow (37.6-47.2\% of head length
[HLL]). Mouth slightly subterminal; maxillary short in length (24.5-31.2\% of HLL) to near middle of eye and narrow (6.9-10\% HLL). Eyes mid-set (preorbital length $20-22.6 \%$ of HLL), typically centred on the head along or slightly above midline of body. Eye diameter moderate (27.3-31.1\% of HLL). Interorbital distance moderate (19.5-24.7\% HLL). Gill raker number low, 16-18: 6-7 on upper arch and 10-11 on lower arch. Gill raker length short (3.2-4.7\% of HLL), a distinguishing feature for this species. Dorsal fin moderate in length (10-11.8\% of STL) and height (15.5$18.3 \%$ of STL); outer margin of dorsal fin angular; rays 9-10. Anal fin short at base; rays 9-11. Caudal fin forked and tips angular. Pectoral fins short and outer margin slightly concave; rays variable, 14-16. Pelvic fins short; origin below the second or third branched dorsal rays; rays 10-11; pelvic axillary process present. Adipose small. Lateral line complete, 54-60 scales. See Tables 1 and 2 for mean morphometric measurements and meristic counts.

\section{Colouration}

Live specimens generally silver with brownish dorsal colouration extending ventrally to two or three scale rows above the lateral line. Numerous parr marks present along lateral line and smaller blotches visible along dorsal surface. Anteriorly pigmented mandible and maxilla; paired fins immaculate or yellowish. Caudal fin lightly pigmented. Anal fin immaculate.

TABle 2. Meristic counts for six Pygmy Whitefish (Prosopium coulterii), five females and one unknown gender, at Bluefish Lake, Northwest Territories.

\begin{tabular}{lc}
\hline \hline Meristic count & Mean number \\
\hline \hline Dorsal rays & 10.00 \\
Anal rays & 10.83 \\
Pectoral rays & 15.00 \\
Ventral rays & 10.20 \\
Upper gill rakers & 6.67 \\
Lower gill rakers & 10.17 \\
Lateral line scales & 56.17 \\
\hline \hline
\end{tabular}

TABle 1. Morphometric measurements of six Pygmy Whitefish (Prosopium coulterii), five females and one unknown gender, at Bluefish Lake, Northwest Territories.

\begin{tabular}{lrlr}
\hline \hline Measurement & Mean, mm & Measurement & Mean, mm \\
\hline Trunk length & 114.17 & Caudal peduncle depth & 6.55 \\
Fork length & 105.33 & Interorbital length & 5.03 \\
Standard length & 98.83 & Maxillary length & 6.01 \\
Preorbital length & 4.84 & Maxillary width & 1.99 \\
Orbital length & 6.91 & Pectoral fin length & 16.35 \\
Post orbital length & 11.26 & Pelvic fin length & 15.51 \\
Trunk length & 22.91 & Adipose length & 8.15 \\
Dorsal fin length & 10.56 & Middle gill raker length & 0.89 \\
Dorsal fin height & 16.18 & Lower arch length & 9.26 \\
Caudal peduncle length & 16.62 & Anal fin length & 9.30 \\
Head depth & 9.65 & Lumbar length & 17.50 \\
Body depth & 20.69 & & \\
\hline \hline
\end{tabular}




\section{Reproductive state}

Five of the specimens were females with developed gonads indicating that they were close to spawning. One was in the resting phase and gender could not be determined. Fecundity, measured as total egg number, was determined for three of the five females as 209,211 , and 217 eggs. Egg size ranged from 2.08 to $2.79 \mathrm{~mm}$.

\section{Taxonomic assessment}

Based on scale size, low lateral line scale count, adult parr marks, low gill raker counts, snout proportions, size at maturity, low fecundity, and large egg size, the six specimens collected in Bluefish Lake during our 2012 survey were determined to be Pygmy Whitefish. Specimens are archived at Fisheries and Oceans Canada, Yellowknife.

\section{Habitat data}

The bottom substrate at the sampling station consisted of clay and organic debris. At the depth where the six Pygmy Whitefish were captured, water temperature was $5.3^{\circ} \mathrm{C}$, dissolved oxygen $3.5 \mathrm{mg} / \mathrm{L}$, conductivity $63 \mu \mathrm{S} / \mathrm{cm}$, and $\mathrm{pH} 6.3$.

\section{Discussion}

The capture of Pygmy Whitefish in Bluefish Lake represents only the second observation of this species in the Northwest Territories and the first report of their presence in the Great Slave Lake Basin. It is unclear which glacial refugium was used to recolonize Bluefish Lake. However, the Athabasca population is thought to originate from the Cascadia refugium; thus, it is possible that the Pygmy Whitefish of Bluefish Lake are most closely related to the Columbia River drainage group. (see Appendix I for meristic means of North American Pygmy Whitefish populations studied thus far.) Isolated and small populations of coregonids, such as the Bluefish Lake Pygmy Whitefish, are important from a conservation standpoint because populations are often small and are, therefore, more susceptible to extirpation by stochastic events. It is likely that the distribution data for Pygmy Whitefish are incomplete, possibly because collectors fail to collect this species (Eschmeyer and Bailey 1955), due to their small size and relatively deep depth of capture. They may also be misidentified as juvenile Mountain Whitefish or Round Whitefish where these species co-occur.

\section{Acknowledgements}

Funding and logistical support was provided by Northwest Territories Power Corporation. Numerous people provided much-appreciated feedback and comments on this project, especially Grant Clarke and Gary Ash of Golder Associates Ltd.

Documents Cited (marked * in text)

Hallock, M., and P. E. Mongillo. 1998. Draft Washington State status report for the Pygmy Whitefish. Washington Department of Fish and Wildlife, Olympia, Washington,
USA. 20 pages. Accessed 19 October 2014. http://wdfw .wa.gov/publications/00222/dftpwfsh.pdf

Mackay, W. C. 2000. Status of the Pygmy Whitefish (Prosopium coulteri) in Alberta. Alberta Wildlife Status Report No. 27. Alberta Environment, Fisheries and Wildlife Management Division, and Alberta Conservation Association, Edmonton, Alberta, Canada. 16 pages. Accessed 19 October 2014. http://esrd.alberta.ca/fish-wildlife/speciesat-risk/species-at-risk-publications-web-resources/fish/docu ments/SAR-StatusPygmyWhitefishAlberta-Feb2000.pdf

McPhail, J. D. 2007. The Freshwater Fishes of British Columbia. University of Alberta Press, Edmonton, Alberta, Canada. 620 pages.

Mayhood, D. W. 1992. A preliminary assessment of the native fish stocks of Jasper National Park. Canadian Parks Service, Jasper, Alberta, Canada. 296 pages. Accessed 19 October 2014. http://www.fwresearch.ca/Library_files/May hood\%201992c.pdf

Schultz, L. P. 1941. Fishes of Glacier National Park, Montana. Conservation Bulletin 22. United States Fish and Wildlife Service, West Glacier, Montana, USA. 42 pages.

Sullivan, M. 2011. Status of the Pygmy Whitefish (Prosopium coulteri) in Alberta. Alberta Wildlife Status Report No. 27 (Update 2011). Alberta Environment, Fisheries and Wildlife Management Division, and Alberta Conservation Association, Edmonton, Alberta, Canada. 46 pages. Accessed 28 October 2014. http://esrd.alberta.ca/fish-wild life/species-at-risk/species-at-risk-publications-web-resour ces/fish/documents/SAR-StatusPygmyWhitefishAlbertaJune2011.pdf

\section{Literature Cited}

Bird, F. H., and K. Roberson. 1979. Pygmy whitefish, Prosopium coulteri, in three lakes of the Copper River System in Alaska. Journal of the Fisheries Research Board of Canada 36: 468-470.

Chereshnev, I. A., and M. B. Skopets. 1992. A new record of the pygmy whitefish, Prosopium coulteri, from the Amguem River basin (Chukotski Peninsula). Journal of Ichthyology 32(4): 46-55.

Eschmeyer, P. H., and R. M. Bailey. 1955. The pygmy whitefish, Coregonus coulteri, in Lake Superior. Transactions of the American Fisheries Society 84: 161-199.

Heard, W. R., and W. L. Hartman. 1965. Pygmy Whitefish in the Naknek River system of southwest Alaska. Fisheries Bulletin 65: 555-579.

Lindsey, C. C., and W. G. Franzin. 1972. New complexities in zoogeography and taxonomy of the pygmy whitefish (Prosopium coulteri). Journal of the Fisheries Research Board of Canada 29: 1772-1775.

McCart, P. J. 1963. Growth and morphometry of the pygmy whitefish (Prosopium coulteri) in British Columbia. M.Sc. thesis, University of British Columbia, Vancouver, British Columbia, Canada. 97 pages.

McCart, P. 1970. Evidence for the existence of sibling species of pygmy whitefish (Prosopium coulterii) in three Alaskan lakes. Pages 81-98 in Biology of Coregonid Fishes. Edited by C. C. Lindsey and C. S. Woods. University of Manitoba Press, Winnipeg, Manitoba, Canada.

McPhail, J. D., and C. C. Lindsey. 1970. Freshwater fishes of northwestern Canada and Alaska. Bulletin 173. Fisheries. Research Board of Canada, Ottawa, Ontario, Canada.

Mecklenburg, C. W., T. A. Mecklenburg, and L. K. Thorsteinson. 2002. Fishes of Alaska. American Fisheries Society, Bethesda, Maryland, USA. 1037 pages. 
Nelson, J. S., and M. J. Paetz. 1992. The Fishes of Alberta, 2nd edition. University of Alberta Press, Edmonton, Alberta, Canada. 438 pages.

Scott, W. B., and E. J. Crossman. 1973. Freshwater fishes of Canada. Bulletin 184. Fisheries Research Board of Canada, Ottawa, Ontario, Canada. 966 pages.

Vuorinen, J. A., Bodaly, R. A., Reist, J. D., Bernatchez, L., and Dodson, J. J. 1993. Genetic and morphological differentiation between dwarf and normal size forms of lake whitefish (Coregonus clupeaformis) in Como Lake, Ontario. Canadian Journal of Fisheries and Aquatic Sciences 50: 210-216.
Wiedmer, M., D. R. Montgomery, A. R. Gillespie, and H. Greenberg. 2010. Late Quaternary megafloods from Glacial Lake Atna, Southcentral Alaska, USA. Quaternary Research 73: 413-424.

Weisel, G. F., and J. B. Dillon. 1954. Observations on the pygmy whitefish, Prosopium coulteri, from Bull Lake, Montana. Copeia 1954: 124-127.

Weisel G. F., D. A. Hanzel, and R. L. Newell. 1973. The pygmy whitefish, Prosopium coulteri, in western Montana. Fishery Bulletin 71: 587-596.

Received 15 May 2013

Accepted 8 May 2014 


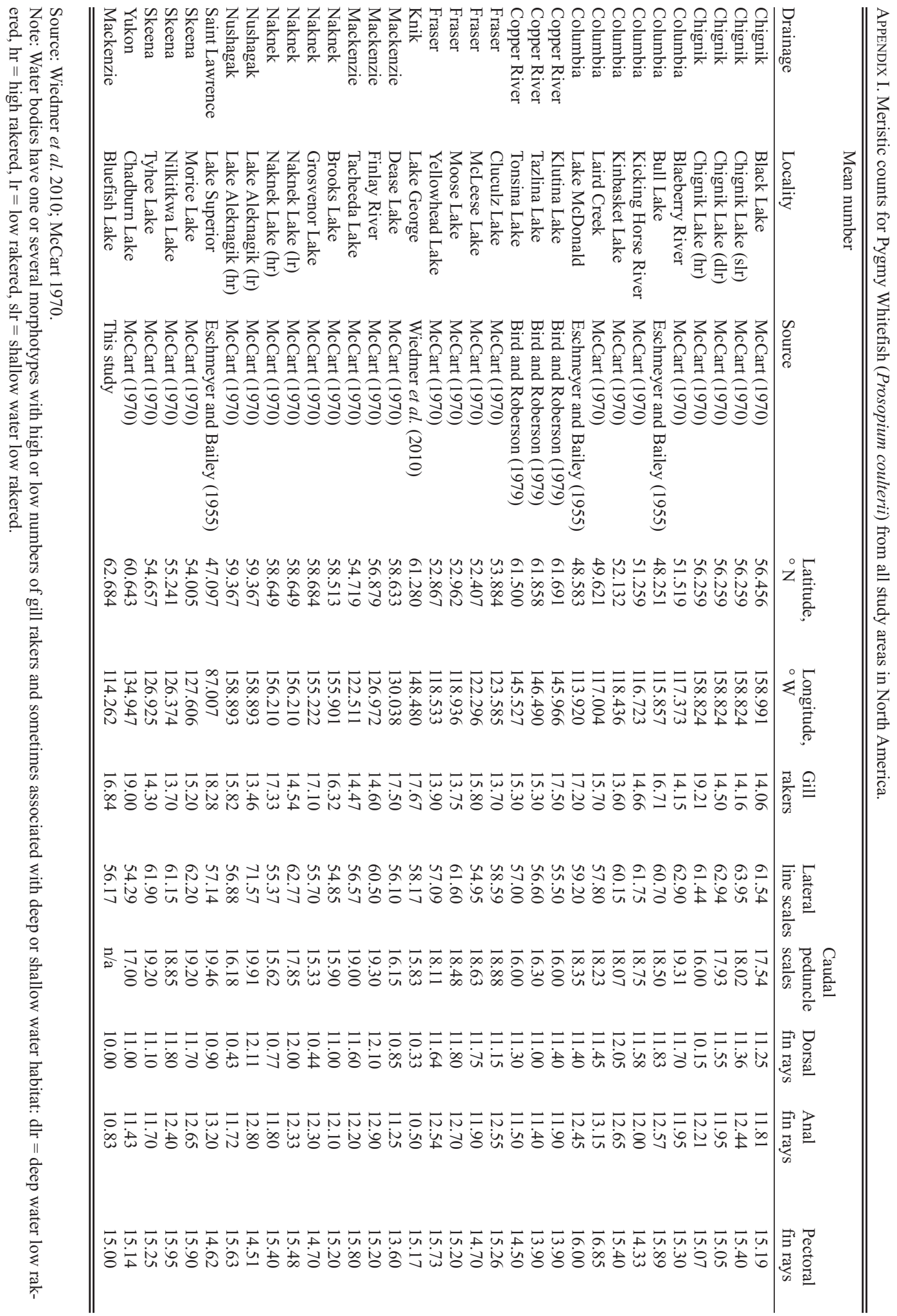

